\title{
Proposed power transmission lines in Cambodia constitute a significant new threat to the largest population of the Critically Endangered Bengal florican Houbaropsis bengalensis
}

\author{
Simon P. Mahood, Joño P. Silva, Paul M. Dolman and Robert J. Burnide
}

\begin{abstract}
The remaining Indochina population of the Critically Endangered Bengal florican Houbaropsis bengalensis breeds in the floodplain of Cambodia's Tonle Sap Lake. The population has declined substantially but survival rates have not been published previously. Survival could potentially be reduced by the planned construction of hightension power transmission lines that may begin in 2016 . Using data from 17 individuals monitored by satellite transmitters over 4 years we estimated the annual adult survival rate to be $89.9 \%$ (95\% CI 82.2-97.6\%), which is comparable to that of other bustards. Interrogation of movement paths revealed that for the 13 individuals for which we had sufficient data for non-breeding seasons, all annual migration routes between breeding and non-breeding areas crossed the proposed route of the transmission line. The route also impinged on the margins of one important and one minor breeding concentration. A review of bustard collision rates confirmed the vulnerability of bustards to power lines, and the proposed development therefore presents an additional threat to the future of this species in Indochina.
\end{abstract}

Keywords Bengal florican, bustard, Cambodia, collision mortality, Houbaropsis bengalensis, power line, Tonle Sap

\section{Introduction}

$\mathrm{D}$ apid economic growth drives increasing energy deRmands (Toman \& Jemelkova, 2003). In South-east Asia this demand is being met through the development of hydropower dams on the Mekong River and its tributaries (MRC, 2011), with the inevitable construction of associated high-voltage power transmission lines. Power lines are a

\footnotetext{
Simon P. MahooD* (Corresponding author) Wildlife Conservation Society Cambodia Program, Phnom Penh, Cambodia. E-mail smahood@wcs.org

Jō̃o P. SILVA† Redes Energéticas Nacionais Biodiversity Chair, CIBIO/InBIO Associate Laboratory, Universidade do Porto, Vairão, Portugal

Paul M. Dolman and Robert J. Burnside School of Environmental Sciences, University of East Anglia, Norwich, UK

*Also at: Research Institute for the Environment and Livelihoods, Charles Darwin University, Darwin NT 0909, Australia

$\dagger$ Also at: Faculdade de Ciências da Universidade de Lisboa, Centre for Ecology, Evolution and Environmental Changes, Lisbon, Portugal

Received 3 February 2016. Revision requested 24 March 2016.

Accepted 23 June 2016. First published online 6 December 2016.
}

well-documented threat to birds globally (e.g. Jenkins et al., 2010), with hundreds of millions of birds killed annually through collisions and, to a lesser extent, electrocution (e.g. Rioux et al., 2013; Loss et al., 2014). Collisions have a disproportionate impact on species with high wing-loading and low aspect, whose heavy bodies and small wings restrict rapid reactions to obstacles (Bevanger, 1998), and species with narrow fields of view in the frontal plane, such as storks, cranes and, in particular, bustards (Martin \& Shaw, 2010).

The Critically Endangered Bengal florican Houbaropsis bengalensis occurs in South-east Asia and the Indian subcontinent; $H$. bengalensis blandini is the only bustard taxon in South-east Asia, where it is now restricted to the Tonle Sap floodplain, in Cambodia (Collar et al., 2014). The population declined by an estimated $44-64 \%$ between 2005-2007 and 2012, when only 216 (95\% CI 156-275) displaying males remained (Packman et al., 2014), primarily as a result of rapid loss of floodplain grassland (Packman et al., 2013). The effects of other potential threats, such as hunting and nest predation by domestic dogs, are unknown. Population trends at Cambodian breeding sites vary, although most are negative (Packman et al., 2014); the only stable population is in Stoung-Chikraeng Bengal Florican Conservation Area (WCS Cambodia, unpubl. data, 2016). Bengal floricans disperse annually from their breeding grounds as lake levels rise (Gray, 2008; Packman, 2011), migrating up to $60 \mathrm{~km}$ to degraded Dipterocarp forest and farmland (Packman, 2011). Outside South-east Asia the nominate subspecies is restricted to an estimated 75-96 individuals in Nepal and fewer than 100 in India (BirdLife International, 2016).

Basic demographic parameters, which are important in the diagnosis of population declines, are poorly known for the Bengal florican. Breeding productivity is unquantified; however, a preliminary estimate based on a limited data set indicated potentially high adult survival (Packman, 2011), as is typical for many bustard species (Dolman et al., 2015). The planned construction of a power line adjacent to the major breeding concentrations of the Bengal florican could potentially intercept migration routes between these and non-breeding areas, and could pose a serious threat to this species.

In contrast to most other countries in South-east Asia, Cambodia has a relatively low human population density 
and is still ranked as a Least Developed Country (UNOHRLLS, 2015), with only c. $250 \mathrm{~km}$ of power transmission lines (ADB, 2013). This is set to change over the next few years following the announcement in 2015 of plans for 230 $\mathrm{kV}$ power transmission lines running from Battambang to Siem Reap and along the northern edge of the Tonle Sap floodplain (Fig. 1a) through Kampong Thom and Kampong Cham ( $350 \mathrm{~km}$; hereafter Tonle Sap power line), linking that line at Kampong Thom with the international border with Laos PDR (190 km) and linking Kampong Cham with the Lower Sesan 2 hydropower dam in Stung Treng Province $(125 \mathrm{~km})$ (Electricité du Cambodge, 2015a,b; The Cambodia Daily, 2015). The breeding grounds of $81 \%$ of the Cambodian Bengal florican population are located in the floodplain immediately to the south or along the route of the proposed Tonle Sap power transmission line (Packman et al., 2014; Fig. 1a). In common with most countries Cambodian government policy and practice prioritize economic development. Pre- Environmental Impact Assessments (EIA) were conducted for the proposed Tonle Sap and Kampong Thom-Lao PDR power transmission lines (possibly in advance of a full EIA) and were obtained by the authors after submission of the manuscript. Government press releases issued prior to the pre-EIAs made clear the proposed power transmission lines had been approved by the Prime Minister (Electricité du Cambodge, 2015a,b); they are therefore likely to proceed.

We provide a baseline estimate of annual survival rates of Cambodia's Bengal floricans prior to the construction of power transmission lines. To assess qualitatively the potential impact of power lines on the Bengal florican we reviewed published and unpublished data on rates of collision between bustards and power lines and examined the location of breeding and non-breeding areas and migration routes in relation to planned transmission routes.

\section{Methods}

\section{Mortality rate in the absence of power lines}

During May 2010-January 201511 male (10 adults, 1 subadult) and six female (5 adults, 1 subadult) Bengal floricans were monitored using Argos platform telemetry transmitters (35 g Solar Argos PTT-10o and 45 g Solar Argos/GPS PTT-100 45 g, Microwave Telemetry, Inc., Columbia, USA; $30 \mathrm{~g}$, North Star Science and Technology, King George, USA; Table 1). This sample represented c. $4 \%$ of the 2012 adult population of Bengal floricans in Cambodia (assuming an approximate 1:1 sex ratio). All transmitters had an expected transmission lifespan of $\mathrm{c} .3$ years as stated on their product sheets (Microwave Telemetry, Inc., 2015; North Star Science and Technology, 2015) and remained charged using solar power, except for one non-solar unit with a 1-year life expectancy. Catch methods are described in Packman (2011). The transmitters were attached using permanent Teflon backpack harnesses with no possibility of tag loss, and unit failure was considered to be unlikely. As mortalities could not be interpreted in the field, outcomes were interpreted from engineering data about the activity state of the transmitter, including Argos location classes 2 ( 1 SD of estimated error: 250-500 m) and 3 (1 SD of estimated error: $<250 \mathrm{~m}$ ), and temperature, activity sensor and voltage data (following Burnside et al., 2016). Spatial error in Argos fixes meant that location data alone could not confirm mortality (with uncertainty as to whether a position was static), but location data could confirm that an individual was still alive when seasonal movements exceeded the error margin of location fixes. Mortality was inferred when the activity sensor remained static, the mean unit temperature dropped and the voltage pattern changed from the previous cycle (although the unit typically initially continues to transmit). Sudden cessation of transmission where engineering data had been regular with no indication of voltage deterioration was also attributed to death and subsequent destruction, burying or permanent covering of the solar panel leading to permanent signal loss (Burnside et al., 2016). In contrast, progressive deterioration of the voltage and increasing gaps in transmission of engineering data are signs of transmitter failure. Consequently, the fate of all individuals was known $(1=$ death and $\mathrm{o}=$ unit failure or still alive at the end of the data transmission period), facilitating direct measures of daily mortality rate, with variance estimated by binomial error using the number of exposure days as the number of binomial trials, with the annual survival estimated to be $(1-\text { daily mortality rate })^{365}$.

\section{Assessment of risk from the proposed power lines}

We collated and reviewed quantified estimates of bustard mortality rates from power line collisions, based on published studies located using Web of Science, and unpublished reports that were known to us. To the best of our knowledge only studies in which repeat surveys were conducted on cleared lines were included in our review.

Bengal florican breeding and non-breeding areas were located and mapped based on 10 years of field surveys (Davidson, 2004; Gray et al., 2009; Mahood et al., 2013) and unpublished satellite transmitter data (this study). Movement paths were interpreted from platform telemetry transmitter relocations, filtered using only locations of class 2 or 3. Any locations outside Cambodia were excluded as outliers. To quantify the risk of encountering power lines during annual movements between breeding and nonbreeding areas, movement paths were examined and the occurrence and date of each potential power line crossing event was recorded. 


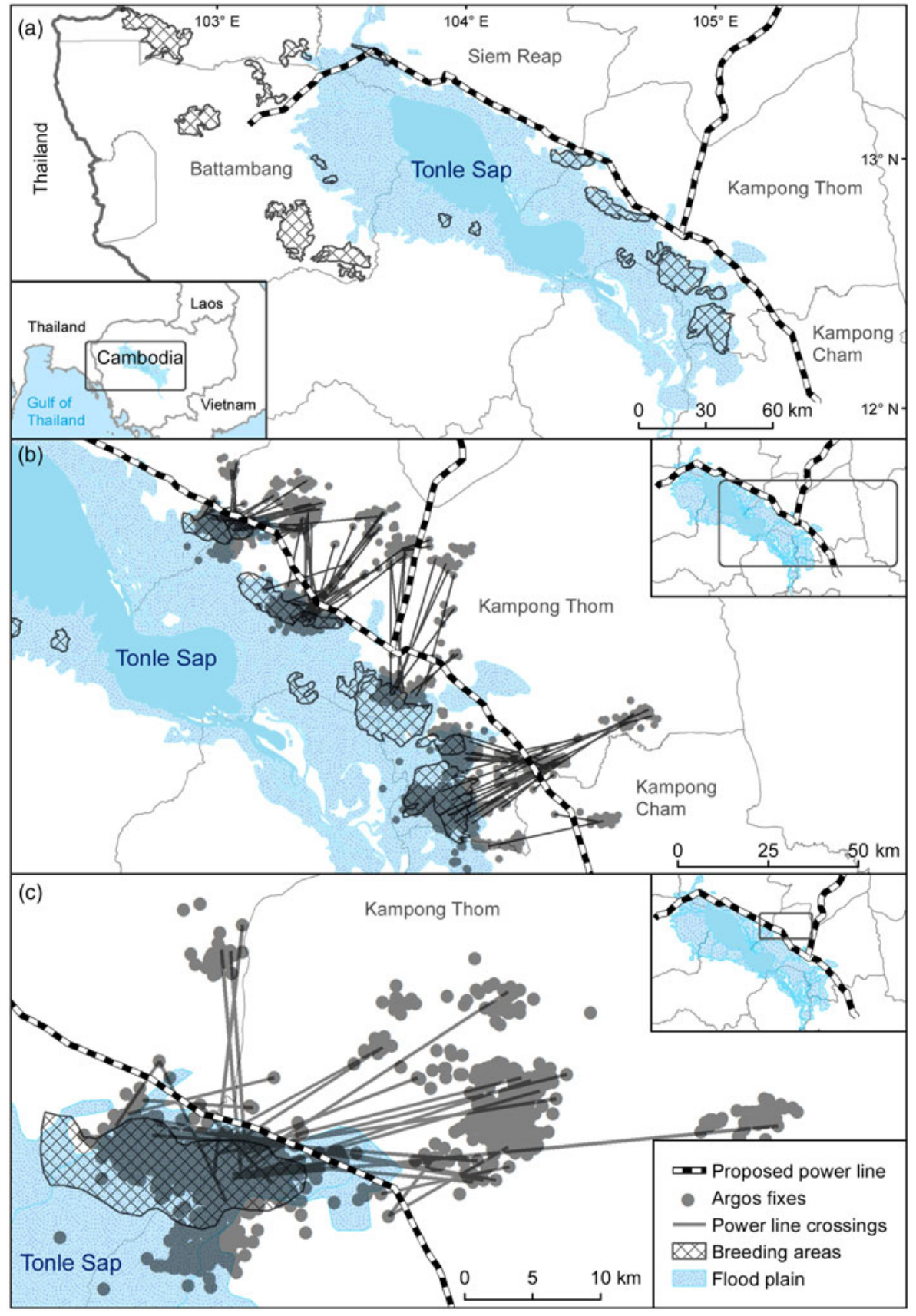

FIG. 1 Locations of breeding sites of the Bengal florican Houbaropsis bengalensis around Tonle Sap Lake in Cambodia, in an area that contains $>50 \%$ of the global population of the species, and the proposed routes for power transmission lines. (b) The movements of 15 Bengal floricans between May 2010 and January 2015 inferred from satellite telemetry data. (c) As in (b) but focused on StoungChikraeng Bengal Florican Conservation Area and associated non-breeding areas.

\section{Results}

Survival rate in the absence of power lines

The rates at which transmitters provided high-quality location fixes (i.e. classes 2 or 3 ) varied between individuals (total $=12,782$ filtered locations; Table 1). A greater frequency of engineering data was received (118,700 lines; Table 1), with fewer gaps ( $54.0 \%$ of exposure days covered), and thus outcomes could be determined for all monitored individuals. The 17 individuals were monitored for a total of 20,566 exposure days between 2010 and the end of January 2015. Three evident mortalities interpreted from engineering data together with three sudden cessations with no prior transmitter failure or battery deterioration (Table 1) indicated a total of six mortalities (one female, five male) during the study. One non-solar powered unit reached its 1 year life-expectancy (Table 1). The other 10 individuals survived and were transmitting until the end of the programme. Annual survival was estimated to be $89.9 \%$ (95\% CI 82.2-97.6\%).

\section{Assessment of risk from the proposed power lines}

Published and unpublished data for five bustard species across 11 studies and five countries (Table 2) confirmed 
TABLE 1 Deployment and outcomes for 17 Bengal floricans Houbaropsis bengalensis tracked via Argos satellite transmitters between May 2010 and February 2015. Argos no. refers to the number of Argos location fixes of quality class 2 or 3. Engineering no. refers to the number of engineering transmissions received containing information on activity, temperature and voltage sensors, from which outcomes can be inferred. Engineering days refers to the number of days during the monitoring period on which engineering data were received. Exposure days refers to the total number of days an individual was monitored alive, as inferred from the Argos and engineering data. Outcomes are self-explanatory (except for EOP: individual alive at end of programme), and coded as $1=$ dead, $o=$ alive on last monitoring day.

\begin{tabular}{|c|c|c|c|c|c|c|c|c|c|c|c|c|}
\hline \multirow[b]{2}{*}{ Tag ID } & \multirow[b]{2}{*}{ Sex } & \multirow[b]{2}{*}{ Deployed } & \multicolumn{3}{|l|}{ Argos } & \multicolumn{3}{|c|}{ Engineering } & \multirow[b]{2}{*}{$\begin{array}{l}\text { Exposure } \\
\text { days }\end{array}$} & \multirow[b]{2}{*}{ Outcome } & \multicolumn{2}{|l|}{ Mortality } \\
\hline & & & $\begin{array}{l}\text { 1st location } \\
\text { date }\end{array}$ & No. & $\begin{array}{l}\text { Last location } \\
\text { date }\end{array}$ & No. & Days & $\begin{array}{l}\text { Last date } \\
\text { engineering received }\end{array}$ & & & Date & Location \\
\hline 67512 & $\mathrm{M}$ & Mar. 2008 & 18 May 2010 & 297 & 23 Jan. 2015 & 572 & 403 & 26 Jan. 2015 & 1,714 & EOP (0) & & \\
\hline 72044 & M & Mar. 2008 & 24 May 2010 & 547 & 28 Jan. 2015 & 1,116 & 634 & 31 Jan. 2015 & 1,713 & EOP (0) & & \\
\hline 72047 & M & Mar. 2008 & 23 May 2010 & 565 & 30 Jan. 2015 & 1,350 & 772 & 1 Feb. 2015 & 1,715 & EOP (0) & & \\
\hline 28410 & $\mathrm{~F}$ & Feb. 2009 & 30 May 2010 & 146 & 3 June 2012 & 247 & 140 & 27 July 2012 & 758 & Death (1) & $\begin{array}{l}27 \text { June } \\
2012\end{array}$ & $\begin{array}{l}12.994^{\circ} \mathrm{N} \\
104.474^{\circ} \mathrm{E}\end{array}$ \\
\hline 90587 & $\mathrm{~F}$ & Feb. 2009 & 18 May 2010 & 1,591 & 1 Feb. 2015 & 15,845 & 1,302 & 1 Feb. 2015 & 1,720 & EOP $(0)$ & & \\
\hline $\begin{array}{l}90588- \\
10\end{array}$ & M & Feb. 2009 & 21 May 2010 & 101 & 3 Aug. 2011 & 857 & 101 & 9 Aug. 2011 & 445 & Sudden stop (1) & 9 Aug. 2011 & $\begin{array}{l}12.439^{\circ} \mathrm{N} \\
105.04^{\circ} \mathrm{E}\end{array}$ \\
\hline 90591 & M & Mar. 2009 & 23 May 2010 & 14 & 15 June 2010 & 141 & 15 & 24 June 2010 & 32 & $\begin{array}{l}\text { End of battery } \\
(0)\end{array}$ & & \\
\hline 52015 & $\mathrm{~F}$ & Feb. 2010 & 28 May 2010 & 677 & 31 Jan. 2015 & 7,432 & 723 & 31 Jan. 2015 & 1,709 & $\mathrm{EOP}(0)$ & & \\
\hline 52117 & M & Feb. 2010 & 18 May 2010 & 423 & 18 Feb. 2012 & 4,739 & 422 & 21 Feb. 2012 & 644 & Death (1) & 21 Feb. 2012 & $\begin{array}{l}12.594^{\circ} \mathrm{N} \\
104.86^{\circ} \mathrm{E}\end{array}$ \\
\hline 52119 & M & Feb. 2010 & 18 May 2010 & 1,097 & 25 Sep. 2012 & 10,979 & 703 & 25 Dec. 2012 & 952 & Sudden stop (1) & $\begin{array}{l}25 \text { Dec. } \\
2012\end{array}$ & $\begin{array}{l}12.266^{\circ} \mathrm{N} \\
104.992^{\circ} \mathrm{E}\end{array}$ \\
\hline 52121 & M & Feb. 2010 & 20 May 2010 & 751 & 31 Jan. 2015 & 8,071 & 767 & 31 Jan. 2015 & 1,718 & EOP $(0)$ & & \\
\hline 52123 & M & Feb. 2010 & 22 May 2010 & 1,626 & 1 Feb. 2015 & 16,645 & 1,083 & 1 Feb. 2015 & 1,716 & EOP (0) & & \\
\hline 52129 & $\mathrm{~F}$ & Feb. 2010 & 18 May 2010 & 468 & 1 Feb. 2015 & 14,776 & 1,190 & 1 Feb. 2015 & 1,721 & EOP (0) & & \\
\hline 52132 & $\mathrm{~F}$ & Feb. 2010 & 20 May 2010 & 2,430 & 1 Feb. 2015 & 18,687 & 1,326 & 1 Feb. 2015 & 1,718 & EOP (0) & & \\
\hline 52133 & M & Feb. 2010 & 18 May 2010 & 438 & 24 Sep. 2011 & 4,304 & 372 & 14 Nov. 2011 & 494 & Death (1) & 25 Sep. 2011 & $\begin{array}{l}12.231^{\circ} \mathrm{N} \\
105.174^{\circ} \mathrm{E}\end{array}$ \\
\hline 52136 & M & Feb. 2010 & 20 May 2010 & 34 & 2 Aug. 2010 & 1,148 & 73 & 4 Aug. 2010 & 76 & Sudden stop (1) & 4 Aug. 2010 & $\begin{array}{l}12.755^{\circ} \mathrm{N} \\
104.676^{\circ} \mathrm{E}\end{array}$ \\
\hline 52137 & $\mathrm{~F}$ & Feb. 2010 & 20 May 2010 & 1,577 & 1 Feb. 2015 & 11,791 & 1,068 & 1 Feb. 2015 & 1,718 & EOP (0) & & \\
\hline
\end{tabular}


TABLE 2 Reported rates of collision between bustards and power lines, with species, location, line type, survey effort, study duration, visit interval, no. of collisions, collision rate, and data source.

\begin{tabular}{|c|c|c|c|c|c|c|c|c|}
\hline Species & Location & $\begin{array}{l}\text { Line } \\
\text { type }^{1}\end{array}$ & $\begin{array}{l}\text { Survey } \\
\text { effort }(\mathrm{km})\end{array}$ & $\begin{array}{l}\text { Study duration } \\
\text { (months) }\end{array}$ & $\begin{array}{l}\text { Visit interval } \\
\text { (days) }\end{array}$ & $\begin{array}{l}\text { No. of } \\
\text { collisions }\end{array}$ & $\begin{array}{l}\text { Collision } \\
\text { rate }\left(\mathrm{km}^{-1} \mathrm{yr}^{-1}\right)\end{array}$ & Source \\
\hline Great bustard Otis tarda & Cáceres, Spain & $\mathrm{T}$ & 3.9 & 24 & $30-60$ & 23 & 2.95 & Janss \& Ferrer (1998) \\
\hline Little bustard Tetrax tetrax & Cáceres, Spain & $\mathrm{T}$ & 3.9 & 24 & $30-60$ & 25 & 3.21 & Janss \& Ferrer (1998) \\
\hline Great bustard & Rosalejo, Spain & $\mathrm{T}$ & 10 & 12 & 15 & 1 & 0.10 & Alonso \& Alonso (1999) \\
\hline Little bustard & Rosalejo, Spain & $\mathrm{T}$ & 10 & 12 & 15 & 12 & 1.20 & Alonso \& Alonso (1999) \\
\hline Little bustard & Almaraz, Spain & $\mathrm{T}$ & 10 & 12 & 15 & 2 & 0.20 & Alonso \& Alonso (1999) \\
\hline Great bustard & Usagre, Spain & $\mathrm{T}$ & 10 & 12 & 15 & 1 & 0.10 & Alonso \& Alonso (1999) \\
\hline Little bustard & Puerto Lápice, Spain & $\mathrm{T}$ & 10 & 12 & 15 & 2 & 0.20 & Alonso \& Alonso (1999) \\
\hline Great bustard & $\begin{array}{l}\text { Ferreira do Alentejo, } \\
\text { Portugal }\end{array}$ & $\mathrm{T}$ & 48 & 12 & 30 & 9 & 0.19 & Neves et al. (2005) \\
\hline Little bustard & $\begin{array}{l}\text { Ferreira do Alentejo, } \\
\text { Portugal }\end{array}$ & $\mathrm{T}$ & 48 & 12 & c. 30 & 19 & 0.40 & Neves et al. (2005) \\
\hline Houbara bustard Chlamydotis undulata & Lanzarote, Spain & $\mathrm{D}$ & 140 & 6 & 182 & 33 & 0.47 & Lorenzo \& Ginovés (2007) \\
\hline Houbara bustard & Fuerteventura, Spain & $\mathrm{D}$ & 227 & 6 & 182 & 38 & 0.33 & Lorenzo \& Ginovés (2007) \\
\hline Great bustard & Castro Verde, Portugal & $\mathrm{T}$ & 11 & 16 & 15 & 23 & 1.57 & Marques et al. (2007) \\
\hline Little bustard & Castro Verde, Portugal & $\mathrm{T}$ & 11 & 16 & 15 & 26 & 1.77 & Marques et al. (2007) \\
\hline Great bustard & Ervidel, Portugal & $\mathrm{T}$ & 5.8 & 12 & 15 & 6 & 1.03 & Marques et al. (2007) \\
\hline Great bustard & Castro Verde, Portugal & $\mathrm{D}$ & 50 & 12 & 15 & 5 & 0.10 & Marques et al. (2008) \\
\hline Little bustard & Castro Verde, Portugal & $\mathrm{D}$ & 50 & 12 & 15 & 15 & 0.30 & Marques et al. (2008) \\
\hline Ludwig's bustard Neotis ludwigii & $\begin{array}{l}\text { Helios-Juno, South } \\
\text { Africa }\end{array}$ & $\mathrm{T}$ & 252 & 24 & 90 & 214 & 0.42 & Shaw (2013) \\
\hline Kori bustard Ardeotis kori & $\begin{array}{l}\text { Aries-Helios, South } \\
\text { Africa }\end{array}$ & $\mathrm{T}$ & 252 & 24 & 90 & 22 & 0.04 & Shaw (2013) \\
\hline Karoo korhaan Eupodotis vigorsii & $\begin{array}{l}\text { Hydra-Kronos, South } \\
\text { Africa }\end{array}$ & $\mathrm{T}$ & 252 & 24 & 90 & 21 & 0.04 & Shaw (2013) \\
\hline Great bustard & Castro Verde, Portugal & $\mathrm{D}$ & 29.7 & $\begin{array}{l}\text { mean } 18 \text { (range } \\
8-31)^{2}\end{array}$ & 15 & 18 & 0.40 & LPN (2012) \\
\hline Little bustard & Castro Verde, Portugal & $\mathrm{D}$ & 29.7 & $\begin{array}{l}\text { mean } 18 \text { (range } \\
8-31)^{2}\end{array}$ & 15 & 28 & 0.63 & LPN (2012) \\
\hline Houbara bustard & Bukhara, Uzbekistan & $\mathrm{T}$ & 126 & 1.3 & $11-13$ & 2 & 0.15 & Burnside et al. (2015) \\
\hline Houbara bustard & Bukhara, Uzbekistan & $\mathrm{D}$ & 114 & 1.3 & $11-13$ & 2 & 0.16 & Burnside et al. (2015) \\
\hline
\end{tabular}

${ }^{1} \mathrm{~T}$, transmission; D, distribution.

${ }^{2}$ Study consisted of a number of surveys, which varied in duration. 
that bustards, including relatively small species, are vulnerable to mortality as a result of collisions with power lines. These studies varied in duration (2-24 months) and in population size and/or density, flight propensity and methods and frequency of searches for carcasses but yielded a mean of 0.69 detected bustard collision fatalities per $\mathrm{km}$ per year (range 0.04-3.21 km $\mathrm{kr}^{-1} \mathrm{yr}^{-1}$ ).

Fifteen Bengal floricans with satellite transmitters were monitored until they had reached the flooding period and initiated non-breeding movements (Fig. 1b). In 2010 not all individuals undertook wet-season migration, whereas in 201113 moved to non-breeding areas and two died around the time of migration (Fig. 2). All 13 migrating individuals crossed the proposed route of the Tonle Sap power transmission line, typically twice in each non-breeding season, during outward and return movements (Fig. 2). However, some individuals' breeding areas were overlapping or close to that proposed power line, indicating a potential to come into contact with the power line more frequently than just during seasonal movements (Fig. 1c).

\section{Discussion}

The annual adult survival rate of tagged Bengal floricans (89.9\%) was comparable to that of other long-lived, slow-reproducing large bustards, such as the great bustard Otis tarda (90.9 \pm SE 1.6\%; Martín et al., 2007) and the Asian houbara Chlamydotis undulata (92.5\%; Combreau et al., 2001). The limited satellite telemetry data available do not suggest age- or sex-related differences in movements or mortality. Of the six satellite-tagged Bengal floricans that died during the study three died in August or September, when the birds had moved a short distance from the breeding grounds but remained in the densely populated outer floodplain, where they are vulnerable to disturbance and hunting. The relatively high adult survival, along with low clutch size (1-2, typically one in Cambodia; Gray, 2008), suggests population dynamics will be sensitive to even a slight change in adult mortality rate, as indicated by demographic modelling for other bustard species (Combreau et al., 2001; Burnside et al., 2012; Dolman et al., 2015).

Migration routes between breeding and non-breeding areas crossed the proposed route of the Tonle Sap power line at least twice each year, with a few individuals that held breeding territories in close proximity to the transmission route crossing more frequently. The mean rate of bustard fatalities as a result of collision with power lines, from collated studies, was 0.69 per $\mathrm{km}$ per year. It is not possible to express this in terms of mortality risk per individual, as studies varied in population size, density, and probably in individual risk (in terms of timing and frequency of flights, and proximity to lines), which probably accounts for some of the variation in mortality rate detected. However, all studies were conducted where power lines crossed areas supporting concentrations of bustards (e.g. Alonso \& Alonso, 1999; Marques et al., 2007; Jenkins et al., 2011; LPN, 2012; Burnside et al., 2015), broadly similar to the situation in Cambodia where subpopulations also vary in density and proximity to proposed power lines. Mortalities resulting from collisions with power lines have been shown to account for a significant proportion of non-natural deaths in a partially migratory population of great bustards, sufficient to influence population demography and behaviour (Palacín et al., 2016).

Demographic impacts of proposed power lines on the Bengal florican in Cambodia cannot yet be quantified, in part because there are insufficient data to quantify the demographic impacts of existing threats (e.g. hunting, nest predation, habitat loss and existing power lines). Nonetheless there is a risk that construction of the proposed Tonle Sap power transmission line will exacerbate ongoing declines and have a detrimental impact on the only significant population of the South-east Asian subspecies of Bengal florican.

Hotspots of high rates of collision with power lines are often reported in studies of avian mortalities (e.g. Shaw et al., 2010; Raab et al., 2012). Identification of areas of high collision risk facilitates targeting of mitigation measures to appropriate areas (Shaw, 2009). The proposed Tonle Sap power transmission line bisects one breeding site (Pouk) with at least five displaying males and passes within $1 \mathrm{~km}$ of Stoung-Chikraeng Bengal Florican Conservation Area, the only site with a stable population of Bengal floricans (Mahood \& Chamnan, 2013). Of the c. 40 displaying males that use Stoung-Chikraeng, the density of birds is highest within a few kilometres of that proposed power transmission line (S.P. Mahood, pers. obs.). Male floricans make aerial displays (Collar et al., 2014) within an exploded lek (Davidson, 2004) and at the beginning of the breeding season aerial disputes for lek position can be seen daily (S.P. Mahood, pers. obs.). Birds are particularly vulnerable to collision with power lines during aerial displays (Henderson et al., 1996).

Although most non-breeding areas were located north of the proposed Tonle Sap power line, one satellite-tagged bird from Baray Bengal Florican Conservation Area spent a single non-breeding season in the vicinity of the proposed route for the Tonle Sap power line and it is likely that others would do the same in years where flooding is incomplete.

The proposed power transmission lines may also affect other vulnerable species. The breeding sites of the Bengal florican are used by a significant number of sarus cranes Antigone antigone, another species prone to collision (Sundar \& Choudhury, 2005), and categorized as Vulnerable on the IUCN Red List. The cranes migrate into the floodplain annually from areas to the north of the proposed Tonle Sap power line. The waterbird colony at 


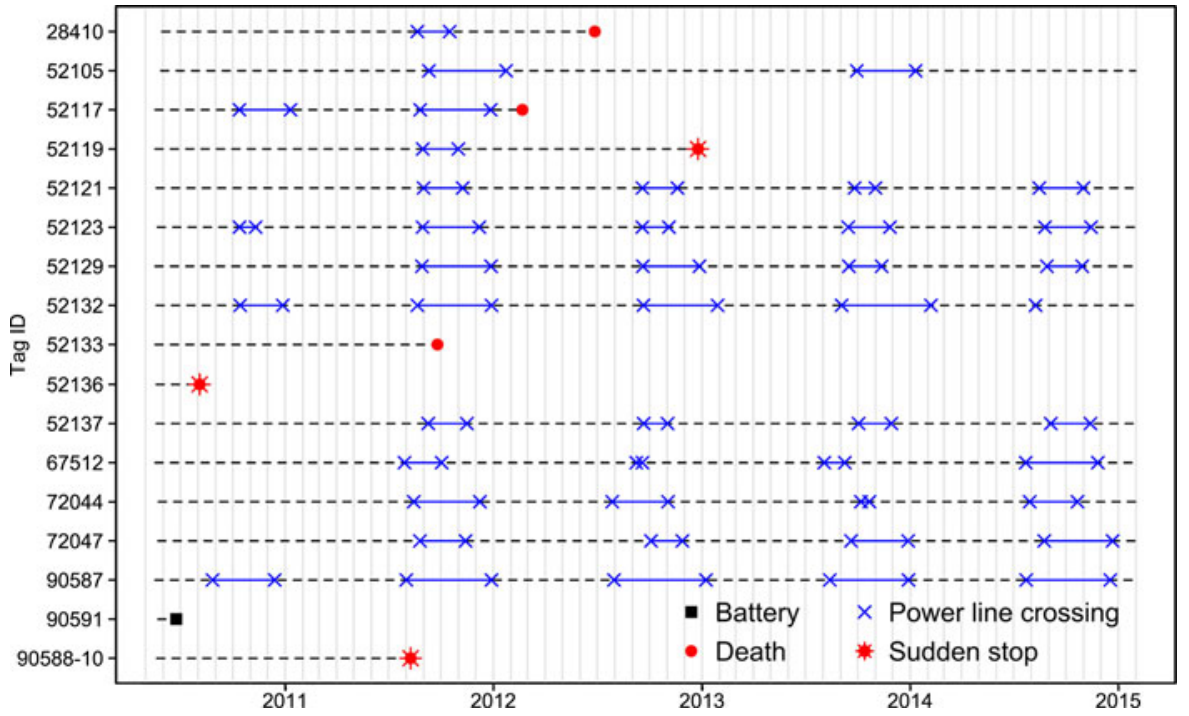

Fig. 2 Duration of satellite monitoring data for 17 Bengal floricans. A dashed line indicates that an individual was on its breeding territory. A solid line indicates that the individual had migrated to the non-breeding territory. The points at which an individual crossed the proposed power line are indicated by $\mathrm{x}$.
Prek Toal, Battambang Province, is located c. $15 \mathrm{~km}$ from that proposed power line; the colony supports at least 40,000 pairs of large waterbirds, including five species of storks, half the global population of the Endangered greater adjutant Leptoptilos dubius and the entire South-east Asian population of the Near Threatened spot-billed pelican Pelecanus philippensis (Sun \& Mahood, 2015). Elsewhere in the floodplain an additional two species of storks and a small population of the Critically Endangered white-shouldered ibis Pseudibis davisoni also breed close to the proposed Tonle Sap power line. All of these large waterbirds disperse widely during the non-breeding season, rendering them vulnerable to collisions. The proposed power line from Kampong Thom to the international border with Laos PDR would pass through forest inhabited by three Critically Endangered vulture species and the Critically Endangered giant ibis Thaumatibis gigantea. The route of the proposed power line from Kampong Cham to the Lower Sesan 2 hydropower dam is unknown but is likely to pass through areas where the white-shouldered ibis and other threatened species breed.

Mitigation measures to reduce the incidence of bird, and especially Bengal florican, collisions with the power lines were not included in the proposed designs but were recommended to the team developing the pre-EIA. Re-routing or burying power lines is considered to be the most effective mitigation measure for bird species that are particularly prone to collisions (Silva et al., 2014). Re-routing sections of the proposed Tonle Sap power line that are otherwise likely to become collision hotspots, such as that near Stoung-Chikraeng Bengal Florican Conservation Area, is important for reducing the number of Bengal florican collisions with the line. Bird collisions with power transmission lines can usually be reduced through the use of bird flight deflectors or line markers, but with high-voltage transmission lines most signalling devices can only be used on the earth cables. The reduction in collisions by using marked cables can be as high as $78 \%$ (Barrientos et al., 2012); however, reductions are species-specific and there is a lower success rate for species with particularly constrained visual fields, such as bustards (Jenkins et al., 2010).

We recommend urgent research and consultation with stakeholders (Electricité du Cambodge, construction companies, financers and communities) to identify appropriate areas where proposed transmission lines could be re-routed, and that appropriate line markers or bird-flight deflectors be installed along the entire network of power lines in Cambodia. As a result of multi-stakeholder consultations that used the analyses presented here, the construction company is considering installing bird-flight deflectors along the section of the power line closest to Stoung-Chikreang Bengal Florican Conservation Area. Given the likely impacts of the proposed power line on Cambodia's globally important population of Bengal floricans and the risks to other threatened waterbirds, it is essential that these mitigation measures be adopted, and their effectiveness monitored.

\section{Acknowledgements}

Funding for satellite transmitters and fieldwork was provided by the Mohammed bin Zayed Species Conservation Fund, the Critical Ecosystem Partnership Fund, Chester Zoo/North of England Zoological Society, North Star Science \& Technology, the Ford Motor Company and the National Avian Research Centre-International Fund for Houbara Conservation. JPS was funded by grant SFRH/ BPD/72311/2010. SPM was funded by the John D. and Catherine T. MacArthur Foundation. We are grateful to Charlotte Packman, who fitted satellite transmitters; 
Markus Handschuh, Son Virak and Jonathan Eames for assistance with fieldwork; and Hong Chamnan, Tom Evans, Robert van Zalinge, Dr Srey Sunleang (Director of the Department of Freshwater Wetlands within the Ministry of Environment), Dr Keo Omaliss (Director of the Department of Wildlife and Biodiversity within the Forestry Administration), the Siem Reap and Kompong Thom Provincial Governments and Kompong Thom Provincial Forestry Administration for advice and assistance. We thank two anonymous reviewers for their helpful comments.

\section{Author contributions}

SPM conceived and wrote the paper, JPS collated bustard collision data, PMD edited the paper, and RJB analysed the satellite transmitter data and drew the figures.

\section{References}

ADb (Asian Development Bank) (2013) Cambodia Power Transmission Lines Co., Ltd., Power Transmission Project: Performance Evaluation Report. Reference No. PPE: CAM 2013-14. Asian Development Bank, Mandaluyong, Philippines.

Alonso, J.A. \& Alonso, J.C. (1999) Colisíon de aves com líneas de transporte de energía eléctrica en España. In Aves y líneas eléctricas (eds M. Ferrer \& G.F.E. Janss), pp. 61-85. Quercus, Madrid, Spain.

Barrientos, R., Ponce, C., Palacín, C., Martin, C.A., Martin, B. \& Alonso, J.C. (2012) Wire marking results in a small but significant reduction in avian mortality at power lines: a BACI designed study. PLoS ONE, 7(3), e32569.

BeVAnger, K. (1998) Biological and conservation aspects of bird mortality caused by electricity power lines: a review. Biological Conservation, 86, 67-76.

Birdife International (2012) Antigone antigone. The IUCN Red List of Threatened Species 2012: e.T22692064A38451823. Http://dx. doi.org/10.2305/IUCN.UK.2012-1.RLTS.T22692064A38451823.en [accessed 14 September 2016].

Birdife International (2016) Species factsheet: Houbaropsis bengalensis. Http://www.birdlife.org [accessed 8 June 2016].

Burnside, R.J., Carter, I., Dawes, A., Waters, D., Lock, L., Goriup, P. \& Székely, T. (2012) The UK great bustard Otis tarda reintroduction trial: a 5-year progress report. Oryx, 46, 112-121.

Burnside, R.J., Collar, N.J., Koshin, M.A. \& Dolman, P.M. (2015) Avian powerline mortalities, including Asian houbara Chlamydotis macqueenii, on the Central Asian flyway in Uzbekistan. Sandgrouse, 37, 161-168.

Burnside, R.J., Collar, N.J., Scotland, K.M. \& Dolman, P.M. (2016) Survival rates of captive-bred Asian houbara Chlamydotis macqueenii in a hunted migratory population. Ibis, 158, 353-161.

Collar, N.J., Garcia, E.F.J. \& Sharpe, C.J. (2014). Bengal florican (Houbaropsis bengalensis). In Handbook of the Birds of the World Alive (eds J. del Hoyo, A. Elliott, J. Sargatal, D.A. Christie \& E. de Juana). Lynx Edicions, Barcelona, Spain. Http://www.hbw.com/ node/53734 [accessed 9 October 2015].

Combreau, O., Launay, F. \& Lawrence, M. (2001) An assessment of annual mortality rates in adult-sized migrant houbara bustards (Chlamydotis [undulata] macqueenii). Animal Conservation, 4, 133-141.
Davidson, P. (2004) The distribution, ecology and conservation status of the Bengal florican Houbaropsis bengalensis in Cambodia. MSc thesis. University of East Anglia, Norwich, UK.

Dolman, P.M., Collar, N.J., Scotland, K.M. \& Burnside, R.J. (2015). Ark or park: the need to predict relative effectiveness of $e x$ situ and in situ conservation before attempting captive breeding. Journal of Applied Ecology, 52, 841-850.

Electricité du Cambodge (2015a) Press Release: $230 \mathrm{kV}$ Electricity Transmission Line Project from Battambang Province-Siem Reap Province-Kampong Thom Province-Kampong Cham Province. Electricité du Cambodge, Phnom Penh, Cambodia.

Electricité du Cambodge (2015b) Press Release: $230 \mathrm{kV}$ Electricity Transmission Line Project from Kampong Thom Province-Preah Vihear Province. Electricité du Cambodge, Phnom Penh, Cambodia.

Gray, T.N.E. (2008) Conservation and ecology of Bengal florican Houbaropsis bengalensis in Cambodia: grasslands, people and management. PhD thesis. University of East Anglia, Norwich, UK.

Gray, T.N.E., Collar, N.J., Davidson, P.J.A., Dolman, P.M., Evans, T.D., Fox, H.N. et al. (2009) Distribution, status and conservation of the Bengal florican Houbaropsis bengalensis in Cambodia. Bird Conservation International, 19, 1-14.

Henderson, I.G., Langston, R.H.W. \& Clark, N.A. (1996) The response of common terns Sterna hirundo to power lines: an assessment of risk in relation to breeding commitment, age and wind speed. Biological Conservation 77, 185-192.

JAnss, G.F.E. \& Ferrer, M. (1998) Rate of bird collision with power lines: effects of conductor-marking and static wire-marking. Journal of Field Ornithology, 69, 8-17.

Jenkins, A.R., Smallie, J.J. \& Diamond, M. (2010) Avian collisions with power lines: a global review of causes and mitigation with a South African perspective. Bird Conservation International, 20, $263-278$.

Jenkins, A.R., Shaw, J.M., Smallie, J.J., Gibbons, B., Visagie, R. \& RYAN, P.G. (2011) Estimating the impacts of power line collisions on Ludwig's bustards Neotis ludwigii. Bird Conservation International, 21, 303-310.

Lorenzo, J.A. \& Ginovés, J. (2007) Bird Mortality Caused by Power Lines in the Steppic Habitats of Lanzarote and Fuerteventura, with Special Reference to the Houbara Bustard. SEO/BirdLife. La Laguna, Tenerife. Http://www.seo.org/lifehubara/Document/informe_ tendidos.pdf [accessed 14 September 2016]. [In Spanish]

Loss, S.R., Will, T. \& Marra, P.P. (2014) Refining estimates of bird collision and electrocution mortality at power lines in the United States. PLoS ONE, 9(7), e101565.

LPN (Liga para a Protecção da Natureza) (2012) Project LiFE Esteparias-Conservation of the Great Bustard, Little Bustard and Lesser Kestrel in the Cereal Fields of Baixo Alentejo-LIFEo7/NAT/P/ 654. Final report of action E4-Monitoring programme. Unpublished report. [In Portuguese]

Mahood, S.P. \& Chamnan, H. (2013) Finding a Place for Bengal Florican in an Agricultural Landscape. Unpublished report. Wildlife Conservation Society Cambodia Program, Phnom Penh, Cambodia.

Mahood, S.P., Virak, S., Chamnan, H. \& Oddam, C. (2013) The Status of Bengal Floricans in the Bengal Florican Conservation Areas, 2012 Monitoring Report. Wildlife Conservation Society Cambodia Program, Phnom Penh, Cambodia.

Marques, A.T., Rocha, P. \& Silva, J.P. (2007) Monitoring the Effects of a High Tension Power Line on Priority Birds. Instituto para a Conservação da Natureza, Lisbon, Portugal. Http://www.erse.pt/pt/ desempenhoambiental/ppda/sectorelectrico/Documents/PPDA\%20 2002-2005/ICN_2005_Protocolo_REN_ICN_Relatorio.pdf [accessed 14 September 2016]. [In Portuguese] 
Marques, A.T., Rocha, P. \& Silva, J.P. (2008) A Complementary Study to Evaluate the Mortality Rate of the Great Bustard (Otis tarda) and Little Bustard (Tetrax tetrax) with Distribution Power Lines in the Special Protection Area of Castro Verde. Instituto de Conservação da Natureza e da Biodiversidade, Lisbon, Portugal. Http://www.erse.pt/pt/desempenhoambiental/ppda/sectorelectrico/ Documents/PPDA\%202006-2008/ICNB_2008_Abetarda_Sisao_ ZPE_Castro_Verde_Relatorio.pdf [accessed 14 Septembe 2016]. [In Portuguese]

Martín, C.A., Alonso, J.C., Alonso, J.A., Palacín, C., Magaña, M. \& MARTín, B. (2007) Sex-biased juvenile survival in a bird with extreme size dimorphism, the great bustard Otis tarda. Journal of Avian Biology, 38, 335-346.

Martin, G.R. \& Shaw, J.M. (2010) Bird collisions with power lines: failing to see the way ahead? Biological Conservation, 143, 2695-2702.

Microwave Telemetry, Inc. (2015) Solar Argos/GPS PTT-10o. Field Manual. Http://www.microwavetelemetry.com [accessed 23 November 2015].

MrC (Mekong River Commission) (2011) Integrated Water Resources Management-based Basin Development Strategy. Mekong River Commission, Vientiane, Laos PDR.

Neves, J., Infante, S. \& Ministro, J. (2005) Impacts of Very High Tension Power Lines on Birds in Portugal. Sociedade Portuguesa para o Estudo das Aves and Quercus Associação Nacional de Conservação da Natureza. Http://www.erse.pt/pt/desempenho ambiental/ppda/sectorelectrico/Documents/PPDA\%202002-2005/ ICN_2005_Protocolo_REN_ICN_Relatorio.pdf [accessed 14 September 2016]. [In Portuguese]

North Star Science and Technology (2015) Turning Tracking and Monitoring into Knowledge. Https://www.northstarst.com/wp/ wp-content/uploads/2012/05/PTT_Marketing.pdf [accessed 23 November 2015].

PACKMAN, C.E. (2011) Seasonal landscape use of a critically endangered bustard: the Bengal florican in Cambodia. PhD thesis. University of East Anglia, Norwich, UK.

Packman, C.E., Gray, T.N.E., Collar, N.J., Evans, T.D., Van Zalinge, R.N., Virak, S. et al. (2013) Rapid loss of Cambodia's grasslands. Conservation Biology, 27, 245-247.

Packman, C.E., Showler, D.A., Collar, N.J., Virak, S., Mahood, S.P., Handschun, M. et al. (2014) Rapid decline of the largest remaining population of Bengal florican Houbaropsis bengalensis and recommendations for its conservation. Bird Conservation International, 24, 429-437.

Palacín, C., Alonso, J.C., Martín, C.A. \& Alonso, J.A. (2016) Changes in bird-migration patterns associated with human-induced mortality. Conservation Biology, http://dx.doi.org/10.1111/cobi.12758.

RaAb, R., Schütz, C., Spakovszky, P., Julius, E. \& Schulze, C.H. (2012) Underground cabling and marking of power lines: conservation measures rapidly reduced mortality of West-
Pannonian great bustards Otis tarda. Bird Conservation International, 22, 299-306.

Rioux, S., Savard, J.-P.L. \& Gerick, A.A. (2013) Avian mortalities due to transmission line collisions: a review of current estimates and field methods with an emphasis on applications to the Canadian electric network. Avian Conservation and Ecology, 8(2), 7.

SHAw, J.M. (2009) The end of the line for South Africa's national bird? Modelling power line collision risk for the blue crane. MSc thesis. University of Cape Town, Cape Town, South Africa.

SHaw, J.M. (2013) Power line collisions in the Karoo: conserving Ludwig's bustard. $\mathrm{PhD}$ thesis. University of Cape Town, Cape Town, South Africa.

Shaw, J.M., Jenkins, A.R., Ryan, P.G. \& Smallie, J.J. (2010) A preliminary survey of avian mortality on power lines in the Overberg, South Africa. Ostrich, 81, 109-113.

Silva, J.P., Palmeirim, J.M., Alcazar, R., Correia, R., Delgado, A. \& Moreira, F. (2014) A spatially explicit approach to assess the collision risk between birds and overhead power lines: a case study with the little bustard. Biological Conservation, 170, 256-263.

Sun, V. \& Mahood, S.P. (2015) Wildlife Monitoring of the Prek Toal Ramsar Site, Tonle Sap Great Lake, 2013 and 2014. Unpublished report. Wildlife Conservation Society Cambodia Program, Phnom Penh, Cambodia.

Sundar, K.S.G. \& Choudhury, B.C. (2005) Mortality of sarus cranes (Grus antigone) due to electricity wires in Uttar Pradesh, India. Environmental Conservation, 32, 260-269.

The Cambodia Daily (2015) Malaysian Company to Build \$92M Power Lines. Https://www.cambodiadaily.com/business/malaysian-companyto-build-92m-power-lines-81788/ [accessed 14 September 2016].

Toman, M.A. \& Jemelkova, B. (2003) Energy and economic development: an assessment of the state of knowledge. Energy Journal, 24, 93-112.

UN-OHRLls (United Nations Office of the High Representative for the Least Developed Countries, Landlocked Developing Countries and Small Island Developing States) (2015) About LDCs. Http://unohrlls.org/ about-ldcs/ [accessed 14 September 2016].

\section{Biographical sketches}

Simon MAHOOD attempts to reconcile development interests with the conservation of threatened species. JO Ã O SILVA studies the ecology and conservation of steppe birds, and in particular the impacts of power lines on birds. P A U L D OLM AN leads an inter-disciplinary conservation ecology research team working on evidence-based biodiversity conservation in human-modified landscapes in Europe and Asia. ROBERT BURNSIDE is a conservation biologist with a particular interest in ex situ management and translocations. 